\title{
RETHINKING THE RIGHT TO ABORTION ${ }^{1}$
}

\author{
Anita BLAgOJEVIĆ \\ Associate professor, Faculty of Law Osijek, \\ Josip Juraj Strossmayer University of Osijek \\ E-mail:ablagoje@pravos.hr \\ Ivana TUCAK \\ Associate professor, Faculty of Law Osijek, \\ Josip Juraj Strossmayer University of Osijek \\ E-mail: itucak@pravos.hr
}

\begin{abstract}
The ending of pregnancy is an issue that keeps attracting great attention even today, at the beginning of the 21st century. Since the 1970s, abortion legislation has moved steadily towards liberalization, especially in developed countries around the world. In Europe, only a few countries still prohibit abortion on request. Yet neither the current legislation nor the relevant case law of supreme and constitutional courts have brought about consensus on the justification thereof. An exceptionally delicate matter made so by a wealth of moral, ethical, philosophical, medical, religious, economic, legal and other aspects, abortion is a bone of contention in the general public and many an expert community. The reasoning provided in constitutional reviews of law is lambasted in equal measure by the pro-choice and the pro-life camps, the latter of which are felt in presence and influence despite the ever-growing liberalization. The paper primarily examines the matter of abortion in comparative and Croatian constitutional law and legislation from the perspective of human rights.
\end{abstract}

Key words: human rights, the right to privacy, freedom, dignity.

\footnotetext{
${ }^{1}$ This article has been translated from Croatian by Aleksandra Živković in collaboration with the authors.
} 


\section{Introduction}

Termination of pregnancy has remained a storm center to this day. Since the 1970s, abortion legislation has moved steadily towards liberalization, especially in developed countries around the world. In Europe, only a few countries still prohibit abortion on request. And yet neither the current legislation nor the relevant case law of supreme and constitutional courts has brought about consensus on the justification thereof. An exceptionally delicate matter made so by a wealth of moral, ethical, philosophical, medical, religious, economic, legal and other aspects, abortion is a bone of contention in the general public and many an expert community. The reasoning provided in constitutional reviews of law is lambasted in equal measure by the prochoice and the pro-life camps, the latter of which are felt in presence and influence despite the ever-growing liberalization. Without a doubt, abortion regulation models exert a considerable effect on the ability of women to stand equal with men in all aspects of life (Bader Ginsburg, 1985, p. 375). Empowering women to make their own decisions concerning their motherhood is of key importance for, inter alia, their economic safety that is essential to child rearing, one of the most demanding life experiences (Flatham, 1989, p. 195).

The paper examines the matter of abortion in comparative and Croatian constitutional law and legislation from the perspective of human rights. The first part outlines the constitutional regulation of abortion through the three global waves of liberalization from the 1960s to today. The second part of the paper examines the pivotal decisions on abortion brought by the Federal Constitutional Court of Federal Republic of Germany (GFCC) and the Supreme Court of the United States of America (USSC), in both the 1970s and the 1990s, and analyzes the academic critique of the Courts' position on the matter. The Courts' sagacious reasoning in regard to abortion remains the subject of academic discussion and critique. The third part of the paper explores the impact of international human rights law on national abortion regulation. The final part of the paper examines the right of the woman to abortion and the right of the fetus to life within Croatian legislation.

\section{Comparative overview of constitutional regulation of abortion}

Following a long history of moral condemnation and criminalization, abortion became legally accepted in countries throughout the world within a remarkably short period (Flatham, 1989, p. 168). This is especially manifest in Europe, where a majority of countries legalized abortion on demand in the second half of the 20th century. The first to move toward abortion liberalization were Eastern Bloc countries: Russia was first to legalize abortion, in 1920, with the remaining countries joining in the 1950s (Guillaume and Rossier, 2018, p. 234).It should be pointed out that abortion in the Eastern Bloc was a primary contraception method owing to a near- 
absence of sexual education and restricted availability of other means of contraception (Guillaume and Rossier, 2018, p. 234). By the end of the 20th century, a considerable number of countries around the world had liberalized their abortion laws. Though seemingly observable as a trend, some examples are contradictory thereto. World-wide abortion liberalization progressed through three waves. In the first wave that started in the 1960sCook and Dickens noted that at least 42 countries modified their abortion laws between 1967 and 1977. While a large majority (39) expanded the list of indications for lawful abortion, three then-Communist countries that had already legalized abortion (Bulgaria, Czechoslovakia and Hungary) narrowed access to it (Cook and Dickens, 1978, p. 637).

The underpinnings for the first wave of abortion liberalization lay in various areas of life, but above all related to public health, career development and population (Nijsten, 1990, p. 29). Of note also are the shifts in the discourse of the abortion debates that took shape under the aegis of the feminist movement on both sides of the Atlantic (Nijsten, 1930, p. 35). It was in the early 1970s that the discords over the new legislative solutions left the "legislative arena" and entered the realm of constitutional dispute (Siegel, 2012, p. 1064), whereby most of attention was confined to the prominent decisions of the USSC (Roe v. Wade, 410 U.S. 113 1973, hereinafter Roe) and the GFCC(39 BVerfGE 1 1975, hereinafter Abortion I), owing to both the fact that these courts were among the first to examine the constitutionality of the abortion law and the seemingly dramatic differences in their positions.

The second, smaller-scale wave of abortion law liberalization marked the 1980s and the 1990s. This period saw liberalization of abortion legislation in Belgium, Greece, and Spain as well as amendments to the decisions of the USSC (Planned Parenthood of Southeastern Pennsylvania v. Casey, 505 U.S. 833 1992, hereinafter Casey) and the GFCC (88 BVerfGE 203 1993, hereinafter Abortion II). In the newly united Germany, the latter court had to re-adjudicate the respective case due to the newly emerged disparities in abortion regulation. Not unlike other Communist countries, the liberal abortion legislation of the German Democratic Republic derogated greatly from that of the Federal Republic of Germany whose 1975 Constitutional Court decision declared abortion unconstitutional (Harel, 2014, p. 42). The East German parliament approved abortion at the request of a pregnant woman in 1972 (The New York Times, 1972).

During the third and final wave, spanning the last two decades, abortion legislation was liberalized in nearly 30 countries around the world (Abortion Worldwide 2017). In the constitutional sense, this is a key period in Europe during which the constitutionalizing of pregnancy termination "changed the doctrine in constitutional courts' decisions on the legislation of the developed European democracies" (Kostadinov, 2017, p. 2). In France (2001, 2014, 2016), Slovakia (2007), Portugal (2010), and Spain (2010, these courts confirmed the constitutionality of the law that permits women to freely choose to terminate their pregnancy within a specific period of gestation. 
According to Abortion Worldwide 2017, abortion legislation was liberalized by 28 countries between 2000 and 2017. Countries that have permitted abortion on demand lie largely in the Northern Hemisphere, which includes most of the European countries. In 2017, 29 out of 43 countries in Europe permitted abortion on demand, which allowed legal access to abortion to $72 \%$ of European women of childbearing age (Guillaume and Rossier, 2018, p. 234). While abortion on demand in Europe is permitted mainly in earlier stages of pregnancy (up to the 12th week), some countries permit abortion on demand up to the 18th week (Sweden) and the 24th week (the Netherlands and United Kingdom) (Singh et al, 2018, p. 18; Guillaume and Rossier, 2018, p. 226).

Outside the above time limits, abortion is permitted under exceptional circumstances, such as pregnancy presenting a threat to the woman's life or health, or in case of severe fetal impairment. In terms of procedural aspects, legislation of a portion of European countries provides for a so-called period of reflection (up to 7 days) prior to having an abortion, as well as counseling (mandated or optional) (Stanescu and Nemtanu, 2015).

A comparative analysis of European legislation shows that abortion law is restrictive in a minority of countries. Abortion is prohibited in Andorra, Malta, San Marino and the Vatican (Guillaume and Rossier, 2018, p. 234). Apart from the above four microstates, Polish legislation limits the permissibility of abortion to cases where pregnancy is the result of an offence or where it presents a risk to the woman's life or health or in cases of fetal impairment (Ruling of the Constitutional Court of the Republic of Croatia, hereinafter Ruling, 2017, Paragraph 23. 1). Interestingly, Polish abortion legislation was considerably more liberal during the country's Communist regime. The current abortion law, preceded by numerous legislative amendments, has only been in force since 1993 (Guillaume and Rossier, 2018, p. 234). In Croatia, abortion on demand was legalized in 1969 (General Law on the Interruption of Pregnancy;Perenić, 1990, p. 263).

\section{Constitutional case law}

Constitutional case law relating to 'abortion legislation' is relatively recent and contemporary with the wave of the abortion legislation liberalization of the 1970s (Ruling, 2017.p. 70). The constitutional courts' decisions that regulate the matter of (im)permissibility of abortion may be divided into three periods: 1) the 1970s, during which the constitutionality of abortion law was examined by the GFCC, the USSC and the constitutional courts in Austria, Italy and France; 2) the 1990s, during which the GFCC and the USSC reaffirmed and modified their 1970s decisions; and 3) the 2000s, during which the constitutionality of abortion regulation was decided by the constitutional courts of developed European democracies, namely, France, Portugal and Spain (Ruling, 2017, pp. 15-19; 43-62; 70-75). 
Insofar as the subject matter is concerned, the comparative overview of constitutional courts' decisions indicates that they are an attempt to balance the constitutional rights and values on the one side, and the freedoms and interest of either of two parties (woman and unborn child, as in the case of France and Italy) or three parties on the other side (woman, unborn child and the state, as in the case of Germany and Spain) (Ruling of the Constitutional Court of Croatia, 2017, p. 70).

The "first wave" of abortion legislation liberalization was characterized by the landmark decisions of the USSC and the GFCC. Owing partly to the significance and reputation these courts enjoy at the global level, these 1970s decisions on abortion received the most attention due to the seemingly dramatic differences in the respective rulings (Werner, 1996, p. 571; Beširević, 2007, p. 114). At the beginning of 1990s, during the "second wave" of abortion legislation adjudication, both courts reaffirmed and modified their original judgments. Siegel appropriately concluded that both courts upheld their original positions while providing more autonomy to women in making decisions about motherhood (Siegel, 2014, p. 1068). The following subchapters will analyze the 1970s and 1990s decisions of the GFCC and the USSC, after which the academic criticism thereof will be examined.

\subsection{0s decisions on constitutionality of abortion}

In 1973, the USSC in Roe declared Texas's abortion ban as unconstitutional (in a 7-2 decision), stating that: a) the woman's right to abortion falls within the right to privacy under the Fourteenth Amendment to the US Constitution, i.e. that the right to privacy is sufficiently elastic to include a woman's decision to (not) terminate her own pregnancy; b) the right of privacy is not absolute, but rather legally constrained; and c) the interests of the state with regard to the protection of health and prenatal life prevail at a certain point (Roe, Part VIII). The Court divided pregnancy into three trimesters, women have "a privacy right to choose abortion" (Gostin, 2019) in the first trimester of pregnancy, and states are authorized to limit and prohibit abortion in the second and third trimesters (Roe, Part XI; Werner, 1996, 571). The right to abortion is a negative liberty which limits state interference with the right of women to abortion, as elucidated by the Court in Maher v. Roe (432 U.S. 464, 474 1977), but does not imply any right to state aid (Walen, 1997, p. 1058).

While the USSC declared the legislation that prohibits abortion unconstitutional in order to protect the autonomy of the woman in deciding on her pregnancy, by contrast, the GFCC, in its 1975 decision, declared unconstitutional the legislation that permitted abortion on request in order to protect unborn life during the first trimester on grounds of violation of the right to life from Article 2 Paragraph 2 of the Basic Law (Siegel, 2014, p. 1064;Harel, 2014, p. 41). Crucial in this decision is the following: the life developing inside a uterus as an independent legal good falls under the protection of the Constitution. The obligation of the state to provide 
protection does not only prohibit direct interference thereof with the developing life but also requires it to protect and stimulate the developing life (Ruling, 2017, p. 49; Harel, 2014, p. 41). The GFCC thus explicitly recognized the right of the fetus to life and defined the obligation of the state to protect unborn life based on the rights of the fetus to dignity, expounding that "where human life exists, human dignity is present to it; it is not decisive that the bearer of this dignity himself be conscious of it and know personally how to preserve it" (quoted according to Siegel, 2012:363; See also Ruling, 2017, p. 50). The GFCC emphasized that "the right of woman to free development of her personality, which includes the freedom to act in the broadest sense, and thus encompasses the responsibility of the woman to decide against motherhood and the obligations that result there from" is not without limitation. It is limited through the rights of other people, the constitutional order, but also moral laws (quoted according to the Ruling, 2017, p. 50; see also Dixon and Craven Nussbaum, 2012, p. 65). In its assessment, the GFCC took the view that the protection of the life of the fetus and the freedom of the pregnant woman to decide to terminate pregnancy as two constitutional values must "be observed with regard to human dignity as central to the value system of the Constitution" (Ruling, 2017, p. 50). With its decision, the GFCC established the conditions under which abortion is considered available to the political process (Beširević, 2007, pp. 114-5).

\subsection{0s decisions on constitutionality of abortion}

In Casey, the USSC analyzed the constitutionality of the Pennsylvania law that required for (i) "a woman seeking an abortion give her informed consent prior to the abortion procedure, and specified that she be provided with certain information at least 24 hours before the abortion is performed", (ii) "for a minor to obtain an abortion", the minor present "the informed consent of one of her parents", and (iii) "a married woman seeking an abortion...sign a statement indicating that she has notified her husband of her intended abortion" (Casey, Part I).

By way of the joint opinion delivered by a relative majority of three judges (Justices A. Kennedy, S. D. O'Connor and D. Souter), the USSC protected the central right of the woman, as recognized by Roe, to terminate pregnancy before the fetus attains viability, which it justified by reference to the doctrine of stare decisis, but also replaced the rigid trimester model with an "undue burden" that allowed the governments to regulate abortion with a view to their interest to protect unborn life as long as such regulation does not represent an "undue burden" on the decision of the woman. To determine whether an 'undue burden' exists, a legal standard is applied to establish whether or not the "purpose or effect" of a provision of law is to pose major obstacles to a woman seeking an abortion (Casey, Part IV).

This decision thus transferred the legal basis of abortion from the right to privacy to the right to liberty that, in view of the Court, also derives from the 
Fourteenth Amendment to the US Constitution. In its decision, the USSC stated: "These matters, involving the most intimate and personal choices a person may make in a lifetime, choices central to personal dignity and autonomy, are central to the liberty protected by the Fourteenth Amendment" (Casey, Part II). In Casey, the USSC overturned a part of the contested law the husband notification requirement - that in its view imposed 'undue burden'. Due to the risk of spousal and child abuse, the USSC deemed that, in terms of the number of women seeking abortion, such institute would produce the same effect as if Pennsylvania had prohibited abortion altogether (Casey, Part V. C; Walen, 1997, p. 1058). Other 'substantial burdens' were not declared invalid (Walen, 1997, p. 1058), such as the 24-hour delay requirement. The Court held that the 24-hour delay generally does not pose substantial health risks, but rather represents "a reasonable measure to implement the State's interest in protecting the life of the unborn" (Casey, Part V. B; Walen, 1997, p. 1058).

In its 1993 decision, the GFCC reaffirmed its view of abortion as an infringement of the right of the unborn as well as that it is the positive obligation of the state to protect it against everyone, including its own mother (Abortion II, Headnote, Paragraph 3; Harel, 2014, p. 42). Even though the Court reiterated that the protection of the unborn implies criminalizing abortion, it stated that the legislature is not constitutionally prohibited from choosing to introduce a concept of protection (with a view to protecting the fetus) that places weight on preventive mandatory counseling of the pregnant woman to predispose her to preserve her pregnancy (Harel, 2014, p. 42). In the view of the Court, the concept of counseling in early stages of pregnancy is only possible with the support of the mother, and not in opposition to her (Abortion II, Paragraph 183). In this case, the Court expressly recognized that access to abortion was supported by the constitutional right of "the pregnant woman to human dignity and the protection and respect thereof" (Article 1 Paragraph 1), to her right to life (Article 2 Paragraph 2), and "her right to free development of her personality" (Article 2 Paragraph 1) (Abortion II, Paragraph 153;see also Dixon and Craven Nussbaum, 2012, p. 65).

The Court identified the state's obligation to undertake suitable measures to provide "adequate and effective", protection of the life of the unborn (Abortion II, Headnote, Paragraph 6). The legislature was given the option to fulfill its obligation to a preventive and not repressive effect by way of counseling. In the case that legislature chose a counseling model to fulfill its duty towards unborn life and the woman decides to terminate her pregnancy following the prescribed mandatory counseling within the first twelve weeks of her pregnancy, her abortion carried out by a physician shall not be punishable (Abortion II, Paragraphs 191 and 418). 


\subsection{Critical review}

In the United States, Roe has received extensive criticism from the academic community, from both the pro-choice and pro-life camps (Bader Ginsburg, 1985; Rausch, 2012, p. 30). In keeping with Sustein's highlighting of the faults of the Roe opinion (Sunstein, 1992, pp. 29-30), this paper will first examine the criticism of grounding Roe on the status of the fetus, and secondly the criticism of the inadequacy of grounding the right to abortion on the principle of privacy. Lastly, the paper will consider the alternative approach that grounds the right to abortion on the principle of gender equality, as proposed by Sustein and Bader Ginsburg.

According to the reasoning in Roe, the right to abortion hinges on the status of the fetus (Walen, 1997, p. 1060). Those committed to the view that the fetus should receive the legal protection enjoyed by persons are devoted to rebutting Roe (Walen, 1997, p. 1062). The right-to life camp emphasizes that the right of states to regulate abortion derives from the democratic principle (Reingold\&Gostin, 2019). The key issue here is the justified reasons for preventing state legislatures from defining personhood to include the fetus (Walen, 1997, p. 1062). Provisions of law that concern the fetus are changing, irrespective of the matter of abortion. Emerging trends have motivated certain lawyers and philosophers to support the introduction of rights of the fetus into the human rights system. Wellman offers an example of the "right to not be born into a life not worth living caused by medical malpractice" (Wellman, 2020 , p. 66). Wrongful life is a legal action recognized in some legal systems. Flatham recapitulates arguments in favor of recognizing the rights of the fetus as grounded in the notion that the fetus is a living being displaying "clear signs of sentience", i.e. basic consciousness. Such arguments suggest that the fetus displays a certain degree of "complex or reflexive consciousness" (the ability of the fetus to feel pain and attempts to avoid it) detectable with scientific instruments (Flatham, 1989, p. 197).

Those seeking recognition of the rights of the fetus fear that the recognition of the right to abortion will open the gate to the reduction of the right to life in other contexts as well. Furthermore, it might lead to the legalization of euthanasia or assisted suicide (Flatham, 1989, p. 197). It is important to emphasize that this dimension is not based on any kind of rational discussion, since the view in which the fetus is a person cannot be scientifically proven nor disproven (Walen, 1997, p. 1062).

The second stream of criticism is directed at the privacy doctrine in the context of abortion. Both sides criticize this doctrine on the grounds that it is not explicitly mentioned in the constitution, but its origin is derived from an article by L. D. Brandeis and S. D. Warren, entitled The Right to Privacy, published in the Harvard Law Review in 1890 (Rausch, 2012, p. 30). Per Roe, the right to abortion forms part of the right to privacy that implies control over one's own body without state limitations(Sunstein, 1992, p. 30). Pro-choice proponents believe the right to abortion should rest on the principle of equal 
protection (Reingold\&Gostin, 2019; Rausch, 2012, p. 33; Sunstein, 1992, p. 31). In favor of such approach, Sunstein finds that abortion bans are unconstitutional on grounds of involving a cooptation of female reproductive organs for the protection of the fetus. The author holds that limiting of abortion arbitrarily transforms female reproductive capacities into a means available to "the use and control of others", while no equivalent disadvantage is exacted on such male capacities (Sunstein, 1992, pp. 31-2; Rausch, 2012, p. 33). In contrast to the principle of privacy, this approach does not require a firm position on the status of the fetus (Sunstein, 1992, p. 32). It recognizes that "in important aspects", the fetus is a human being (Sunstein, 1992, p. 32), and, as such, is aligned with the argument that the destroying of the fetus is "a morally problematic act" at its minimum. However, under this approach, the state cannot exact on women exclusively the obligation to protect the fetus by means of "a legal act of bodily co-optation" (Sunstein, 1992, p. 32). Abortion does not constitute murder of the fetus but rather denying the use of one body to provide sustenance to another (Sunstein, 1992, p. 32). In summary, the argument of equality includes the following assertions: "(1) prohibiting abortion is a form of prima facie or de jure sex discrimination; (2) it is impermissibly selective; (3) it results from constitutionally unacceptable stereotypes; and (4) it fails sufficiently to protect fetal lives" (Sunstein, 1992, p. 32). Per Sunstein, neither of the above points are self-subsistent (Sunstein, 1992, p. 32). Instead, their strength derives from "their cumulative effect" (Sunstein, 1992, p. 32).

Among the supporters of this view is the eldest active justice of the US Supreme Court, Ruth Bader Ginsburg. In her 1985 essay, Bader Ginsburg stressed the failure of the USSC to shape abortion-related issues as a form of gender discrimination (Reingold\&Gostin, 2019). As Bader Ginsburg puts it, not only did the USSC in Roe fail to settle the issue of abortion in the US conclusively, but it also inspired the anti-abortion camp. In her view, the USSC decision to analyze right to abortion "under a substantive due process/personal autonomy headline", and not through a prism that expressly correlates to discrimination against women, was wrong (Bader Ginsburg, 1985, pp. 375-6). Bader Ginsburg further points out that Roe prompted widespread criticism of the Court, strengthened a right-to-life movement and numerous protests that have continued since the decision, including annual proposals to overrule Roe by constitutional amendment as well as a series of legislative measures aimed at limiting its effect (Bader Ginsburg, 1985, pp.379; 381). In their 2019 paper, Reingold and Gostin confirm the 34-year old predictions of Bader Ginsburg. The number of state laws restricting abortion, in terms of the time frame and permissible circumstances, increased "from an average of 14 (between 1983 and 2010) to 57 (between 2011 and 2015) restrictions per year" (Reingold\&Gostin, 2019). This trend continues. Given the appointments of two conservative members to the Supreme Court made by the incumbent president, there is a growing concern that the Court will overturn Roe and Casey (Reingold\&Gostin, 2019). In 2019, per Reingold 
and Gostin, Alabama Georgia, Kentucky, Louisiana, Mississippi, Missouri, and Ohio were clearly departing from well-rooted precedents. Alabama introduced a complete prohibition on abortion, while other listed states limited abortion up to the point a fetal heartbeat. States are also revoking exceptions for rape, incest and the physical and mental health of woman(Reingold\&Gostin, 2019). Certain states extended personhood to previable fetuses by including them in the definition of 'person'. The values of equity and justice, as Reingold and Gostin point out, are a challenge to Roe, women who are able to sustain it financially may choose to travel from states with strict abortion regulation to states with more liberal abortion regulation (Reingold\&Gostin, 2019).

In comparing the abortion case law of the USSC with that of the GFCC, the present authors agree to a certain extent with Werner's view that the differences between the decisions of the two courts, though considerable at first, are more of technical and less of practical nature (Werner, 1996, p. 599). The decisions in Roe and Casey, and the 1993 GFCC decision provided for the ultimate decision on abortion to be made at the discretion of the woman (Werner, 1996, p. 599). Instead of encroaching upon the general principle of illegality of abortion, "the system of preventive protection [of the unborn life] through counseling" introduced the discretion of the state not to impose punishment for abortions performed in the first trimester (Werner, 1996, p. 599). In both countries, it is the woman who makes the final decision on abortion (Werner, 1996, p. 599). The decisions of both courts, as Werner points out, "represent converging approaches to regulating abortion" (Werner, 1996, p. 601). The preventive counseling procedure in Germany serves the same purpose as the Pennsylvania abortion law that was disputed in Casey (Werner, 1996, p. 599). While the German legislation strives to liberalize abortion to the fullest extent within its constitutional framework, US states are moving towards restricting it (Werner, 1996, p. 601).

\section{United Nations and abortion}

The last three decades are characterized by significant development of international human rights norms that qualify restrictive regulation of abortion, i.e. deprivation of access to a safe abortion, as violation of human rights (Fine, Mayall and Sepulveda, 2017, pp. 70-1; Zorzi, 2015, p. 413). Since there are no international treaties that explicitly refer to abortion, the impact of international human rights law on national abortion regulation is related to soft law created by different UN bodies (Zorzi, 2015, p. 411). Actors promoting the right to access to an abortion within the framework of the United Nations rely today on the possibility of developing customary international law from soft law documents (Zorzi, 2015, p. 411). The liberalization of abortion in numerous national legal systems has been encouraged by various treaty bodies and their authoritative interpretation of the obligations of state parties, which has been incorporated into individual 
communications, concluding observations, general comments or general recommendations (Fine, Mayall and Sepulveda, 2017, p. 71; Zorzi, 2015, p. 412).

The Human Rights Committee (hereinafter HRC), whose role is to interpret and monitor the implementation of the International Covenant on Civil and Political Rights emphasized in its General Comment No. 28 (2000): Article 3 (the Equality of Rights between Men and Women) that when states draw up their reports on the right to life (Article 6), they shall also provide information on taken measures aimed at preventing women from undergoing "lifethreatening clandestine abortions" (Paragraph 10). The case of K. L. v. Peru (2005) demonstrated that deprivation of access to an abortion in the event of fatal fetal impairments may also constitute violation of Article 7 stipulating prohibition of "cruel, inhuman or degrading treatment" (Fine, Mayall and Sepulveda, 2017, p. 73). In the case of Mellet v. Ireland (2016), the HRC called upon Ireland to amend its abortion legislation and even, if necessary, its Constitution for the purpose of their harmonization with the Covenant. It specifically shed light on "ensuring effective, timely and accessible procedures for pregnancy termination in Ireland", and "measures to ensure that health-care providers are in a position to supply (...) full information on safe abortion services without fearing being subjected to criminal sanctions" (Paragraph 9; Fine, Mayall and Sepulveda, 2017, p. 76). In terms of avoiding putting women's lives in jeopardy due to a failure of states to provide them with access to a safe and legal abortion, recently adopted General Comment No. 36 (2019): Article 6 (Right to Life) is of utmost importance. The Comment urged that although states may introduce measures relating to voluntary termination of pregnancy, "restrictions on the ability of women or girls to seek abortion must not, inter alia, jeopardize their lives subject them to physical or mental pain or suffering that violates article 7 of the Covenant, discriminate against them or arbitrarily interfere with their privacy" (Paragraph 8).

The jurisprudence of the Committee on the Elimination of Discrimination against Women (hereinafter CEDAW), which is the body competent for the implementation of the Convention on the Elimination of All Forms of Discrimination against Women (1979), is also instructive. Although the Convention does not explicitly mention abortion, Article 16.1 (e) thereof is commonly referred to as support to the right to access to an abortion as it provides women and girls with the right "to decide freely and responsibly on the number and spacing of their children and to have access to the information, education and means to enable them to exercise these rights" (Hunt \&Gruszczynski, 2019, p. 730). The resistance to the liberalization of abortion legislation is the reason why some states have made a reservation to this article (Hunt \&Gruszczynski, 2019, p. 730).

In its General Recommendation No. 21: Equality in Marriage and Family Relations, announced in 1994, the CEDAW clearly stated that women are empowered to decide whether they will have children at all and how many 
children they will have (Paragraph 21), and that women must not be restricted by their partners, parents or governments in making this decision (Paragraph 22). Moreover, in its General Recommendation No. 24: Article 12 of the Convention (Women and Health), announced in 1999, the CEDAW warned about discrimination against women and laid down a situation in which the health care system of a state does not offer services that should "prevent, detect and treat illnesses specific to women" (Paragraph 11). The signatory states should refrain from interfering with action taken by women to achieve their health goals and remove barriers that prevent them from getting appropriate health care, such as criminalizing medical procedures that only women need (Paragraph 14). In 2011, the CEDAW intervened in the case of L.C. v. Peru in a way that it explicitly required from the state party to decriminalize abortion if pregnancy results from rape or sexual abuse (Paragraph 9 (B) (iii) ). That was the first time that a human rights body required a state to liberalize its abortion legislation on the basis of an individual communication (Fine, Mayall and Sepulveda, 2017, p. 71). With regard to the right to access to a safe abortion and post-abortion care, it is also important to mention General Recommendation No. 30 on women in conflict prevention, conflict and post-conflict situations (Paragraph 52 (c); Hunt \&Gruszczynski, 2019, p. 730). Furthermore, in 2018, the CEDAW reviewed the restrictive abortion legislation in Northern Ireland within the scope of Article 8 of the Optional Protocol to the Convention on the Elimination of All Forms of Discrimination against Women. The CEDEW recommended the UK to repeal Sections 58 and 59 of the Offenses against the Person Act (1861), which envisage severe prison sentences for a woman who opt for and the doctor who performs an abortion upon her, and to adopt new legislation that would allow abortion on a broader basis than the then applicable one did (abortion was permitted only if the woman's life was endangered or when the pregnancy posed a serious risk to the woman's health), at least in cases involving severe foetal impairment, rape and incest. In cases where pregnancy poses a threat to the physical or mental health of the pregnant woman, termination of the pregnancy should not be conditioned by "'long-term or permanent' effects" (Paragraph 85; Hunt \&Gruszczynski, 2019, p. 730). In accordance with this recommendation, on 22nd October 2019, section 9 of the 2019 Northern Ireland (Executive Formation etc) Act repealed the disputed sections of the Offenses against the Person Act (McGuinness\& Rooney, 2020).

In its General Comment No. 15 (2013): on the right of the child to the enjoyment of the highest attainable standard of health (Article 24), the Committee on the Rights of the Child (hereinafter: the CRC), the body responsible for the interpretation and implementation of the Convention on the Rights of the Child, recommended states to ensure adolescents access to a safe abortion and post abortion care, regardless of whether abortion is legal in their countries (Paragraph 70). States are invited to consider giving children an opportunity to consent to certain medical procedures, among which 
abortion is listed, without permission of their parents or guardians (Paragraph 31). In its General Comment No. 20 (2016): Implementation of the Rights of the Child during Adolescence, the CRC invited states to decriminalize abortion for adolescent girls in all circumstances. This invitation was repeated in the Concluding Observations on the Combined Third to Sixth Reports of Malta in June 2019 (Gravino\&Caruana-Finkel, 2019, p. 289).

\section{Constitutional regulation of abortion in Croatia}

The matter of abortion in Croatia is regulated under the Act on Health Measures for Exercising the Right to Free Decision on the Birth of Children (hereinafter Act). Said Act was adopted in 1978, while Croatia still formed part of the former Socialist Federal Republic of Yugoslavia (SFRY). Enacted over a quarter of a century ago, the Act, with its legal concepts that are grounded in legal categories that no longer exist in the Croatian constitutional structure, is undeniably an outdated legislative solution. It is a direct result of the period and the sociopolitical framework in which the Act was adopted. Nevertheless, despite the Act's formal inconsistencies with the Croatian Constitution, the solutions related to the right to abortion offered by this 1978 Act are considerably in line with the recent (liberalized) trends and standards in comparative law. However, the 1990s democratic shifts in Croatia animated the debate on the inadmissibility of legislative regulation of abortion in Croatia, the relevance of which remains. In the face of the two (unsuccessful) attempts to modify the existing legislative framework initiated in the mid1990s, to date no new law has been passed to regulate the matter of abortion. On 21 February 2017, twenty-six years after the first application to initiate a review of constitutionality of the Act (that was succeeded by six additional applications of natural and legal persons between 1991 and 2016), the Croatian Constitutional Court rejected the applications. In essence, the Croatian Constitutional Court addressed two principal objections of the petitioners: 1) the objection to unconstitutionality of the contested Act on grounds of absence of constitutional basis on which it was adopted, and 2) objection to non-compliance of the contested Act with the Croatian Constitution.

The first objection was built on the notion that the contested Act became entirely unconstitutional upon the expiry of the constitutional basis upon which the Act was adopted, i.e. that the former Socialist Republic of Croatia's (SRC) Constitution automatically expired upon promulgation of the 1990 Constitution. Predictably and with constitutional grounds, the Constitutional Court declared the objection unfounded. In accordance with the principle of state continuity and succession, with regard to the former SRC and SFRY, Croatia principally accepted regulations and acts of the former states up to their harmonization with its own constitutional order. The Constitutional Act on Implementation of the 1996 Croatian Constitution prescribed that the laws, 
regulations and other general acts were to be harmonized by 31 December 1997. Earlier amendments to the Constitutional Act contained the identical provision, but the harmonization time limit was contingent upon other time frames. In its earlier practice, the Constitutional Court took a position on the legal effect of constitutional acts on implementation of the Constitution and the binding nature of the time limits prescribed therein. In its 2012 Report on Legal Force, Nature and Effects of Constitutional Act on Implementation of the Constitution addressed to the Croatian Parliament, the Court found that no earlier Act on Implementation of the Constitution had constitutional force and that the effects of the Act cannot prevent the direct application of the corresponding provisions of the very Constitution, even if it were directly prescribed by it. As regards the prescribed time limits for harmonization, the Court found that they are of instructive rather than mandatory nature. Thus, the "fact that a certain act was adopted under the 'old' Constitution does not in itself imply that they become unconstitutional and expire, but rather that their (non-)compliance with the 'new' Constitution is subject to review on a caseby-case basis" (Paragraph 35). Accordingly, were the legislature to omit observing the instructive time limit for harmonization with the Constitution, the presumption applies that they are harmonized with the Constitution so long as the legislature or Constitutional Court exclude them from legal order by way of a constitutionality review.

Hence, there is no question of competence of the Constitutional Court in terms of constitutionality review of all acts, including those adopted after the promulgation of the 1990 Constitution. The fact alone that the laws were adopted during a different constitutional regime is insufficient to automatically declare them unconstitutional. On the contrary, such declaration would oppose the principle of the rule of law that stands among the highest values of the constitutional order of Croatia (Article 3 to the Constitution) and forms the basis for the interpretation of the Constitution. The second objection rested on the claim of non-conformity of the contested Act with the Constitution, specifically with regard to Article 21 to the Constitution under which all human beings have the right to life. In examining the second objection, the Court proceeded on its earlier view in which the provisions of the Constitution must be interpreted in light of the entire legal order formed under the Constitution so that their interpretation emerges from the entirety of the relationships established there under (Paragraph 41.1).

Regarding the second objection, in terms of Article 35 to the Constitution, the Constitutional Court interprets that the right to privacy to include the right of all to the freedom to make decisions and to self-determination (Paragraph 44.1). In accordance with the above, under Paragraph 45 to its Ruling, the Court defines the interrelationship between unborn life and right of woman to privacy and finds that: 1) unborn life as a value protected by the Constitution enjoys constitutional protection within the meaning of Article 21 of the Constitution to the extent in which it does not conflict with the right of woman to privacy; 2) the right to life of the unborn being is not protected in a 
manner that grants it precedence over or protection greater than that of the right of woman to privacy, and 3) the legislature enjoys discretion in achieving a just balance between the right of woman to freely decide and the right to privacy on the one side, and the public interest to protect unborn life on the other side.

In closing, the Court holds that the answer to the question of when life begins lies outside its jurisdiction, i.e. that it is for the legislature to prescribe a procedure for and period within which termination of pregnancy at the request of the woman may be carried out without restrictions. The Court found the legislative solution for termination of pregnancy at the request of the woman up to the tenth week of pregnancy to be in compliance with the Constitution, i.e. held that the contested legislative solution did not disturb the just balance between the constitutional right of woman to privacy, liberty and personality on the one side, and public interest in protecting unborn life that is guaranteed under the Constitution as a value protected by the Constitution on the other side (Paragraph 46).

The final part of the Ruling appeals to the need to "modernize" the formally obsolete 1978 Act and states that it is for the legislature to introduce into the future Act educational and preventive measures with a view to making abortion an exception and not a rule. On those grounds, the Court provided an instructive period within which the Croatian Parliament is to adopt a new act in line with the findings of the Court. Even though Article 31 to the Constitutional Act on the Constitutional Court of Croatia clearly prescribes that all decisions and orders of the Constitutional Court are binding to all natural and legal persons, and are to be enforced by all government bodies, local and regional self-government units within their constitutional and legislative scope, the legislature has yet to comply with the above order. Nevertheless, failing to comply with the Constitutional Court order to adopt an act within a specified time limit set by the Constitutional Court is hardly a new phenomenon in Croatia. In the case of the Act on the Lease of Apartments (Official Gazette, No. 91/96) the Croatian Parliament met its obligation 20 years after the Constitutional Court had made the respective decision (Official Gazette, No. 68/18).

\section{Conclusion}

Numerous countries have liberalized their abortion regulation in the last fifty years, but not before the constitutionality of the related acts was brought into question in many of jurisdictions. The reasoning of the USSC and the GFCC in subject-matter related decisions have exerted the overwhelming influence. At first glance, the decisions of the two courts seem to be completely opposed. While the US court recognized the right of woman to abortion within the first trimester, the German court declared abortion an unlawful act. However, the German court also found that even though abortion is and 
should remain an offence, the state may choose to substitute preventive counseling for criminal punishment to fulfill its obligation of protecting the fetus (Harel, 2014, p. 42).

The German example shows that there are multiple options to protect a woman's reproductive autonomy. However, despite the practical similarities between the possibilities of German and American pregnant women to obtain abortion at an early stage of their pregnancy (Werner, 1996, p. 601), the use of the language of rights in this context has its particular weight. The paper supports the view that proponents of abortion who have chosen the language of rights have made the right conceptual choice since the concept of rights provides the most complete protection of women's interests in protecting their reproductive autonomy (Flatham, 1989, p. 169).

The international law continues to evolve. The past decades are characterized by significant development of international human rights norms that qualify restrictive regulation of abortion, i.e. deprivation of access to a safe abortion, as violation of women's human rights and gender equality (Fine, Mayall and Sepulveda, 2017, pp. 70-1; Zorzi, 2015, p. 413).

In Croatia, a new act on abortion is yet to be adopted. The Constitutional Court has declared itself non-competent, unlike its German counterpart, in the matter of defining the moment at which human life begins. The Court devolved to the Croatian Parliament the competence to define the procedure and the timeframe within which a woman may autonomously choose to terminate her pregnancy. Regardless of the exact moment thereof, the legislature will have to be cognizant of the fact that the adoption of any legislative solution other than the gestational limits model constitutionalized under the Ruling of the Constitutional Court of Croatia - whether the adoption of a complete abortion ban, or the indication-based model, or the "open-ended" counseling model that discourages abortion, or the calling a referendum on any or all of the above models - will be contrary to the Constitution (Ruling, 2017, Paragraph 5. 1; Kostadinov, 2017, p. 2).

\section{Bibliography}

Americans pay attention? J. Contemp. Health L. \&Pol'y, 10, 1-32.

Beširević, V. (2007). The gods must be crazy: Does constitution speak about bioethics? Anali Pravnog fakulteta u Beogradu, 55 (3), 110-132.

Bundesverfassungsgericht [Federal Constitutional Court of Germany]. (1993, May 28) 2 BvF 2/90. Nos. 2 BvF 2/90, 2 BvF 4/92, and 2 BvF 5/92. Retrieved from

Cook, R. J., \& Dickens, B. M. (1978). A decade of international change in abortion law: 1967-1977. American Journal of Public Health, 68, 637644. 
Dixon, R., \& Nussbaum, M. C. (2012). Abortion, dignity, and a capabilities approach. In B. Baines, D. Barak-Erez\&TsviKahana (Eds.), Feminist constitutionalism: Global perspectives (pp. 64-82). Cambridge University Press.

Fine, J. B., Mayall, K., \&Sepúlveda, L. (2017). The role of international human rights norms in the liberalization of abortion laws globally. Health and Human Rights, 19 (1), 69-80.

Flathman, R. (1989). The theory of rights and the practice of abortion. In Toward a liberalism (pp. 168-205). Ithaca, London: Cornell University Press. Retrieved from www.jstor.org/stable/10.7591/j.ctt207g5mh.10.

Ginsburg, R. B. (1985). Some thoughts on autonomy and equality in relation to Roe v. Wade. N.C. L. Rev., 63, 375-386.

Gravino, G., \&Caruana-Finkel, L. (2019). Abortion and methods of reproductive planning: the views of Malta's medical doctor cohort. Sexual and Reproductive Health Matters, 27 (1), 287-303. doi: 10.1080/26410397.2019.1683127.

Guillaume, A., \&Rossier, C. (2018). Abortion around the world. An overview of legislation, measures, trends, and consequences. "Population" (English edition) Institut National d'ÉtudesDémographiques (INED), 0(2), 217 306.

Harel, A. (2014). Why constitutionalism matters: The case for robust constitutionalism. Critical Analysis of Law and the New Interdisciplinarity, 1 (1), 32-50.

https://legalresearch.blogs.bris.ac.uk/2020/04/a-legal-landmark-inreproductive-rights-the-abortion-northern-ireland-regulations-2020/.

https://sljeme.usud.hr/usud/praksaw.nsf/7114c25caa361e3ac1257f340032f11e /c12570d30061ce54c12580d100416faf/\$FILE/U-I-60$1991 \% 20$ i\%20dr.pdf.

https://tbinternet.ohchr.org/Treaties/CEDAW/Shared\%20Documents/GBR/IN T_CEDAW_ITB_GBR_8637_E.pdf.

https://www.bundesverfassungsgericht.de/SharedDocs/Entscheidungen/EN/19 93/05/fs19930528_2bvf000290en.html.

https://www.law.utoronto.ca/utfl_file/count/documents/reprohealth/croatia_20 17_constitutional.pdf.

https://www.pravo.unizg.hr/_download/repository/Prof._Kostadinov\%2C_Ko nstitucionalizacija_periodnog_modela_prekida_trudnoce_u_Republici_Hr vatskoj.pdf 
Hunt, K., \& Gruszczynski, M. (2019). The Ratification of CEDAW and the Liberalization of Abortion Laws. Politics \& Gender, 15 (4), 722-745.doi: https://doi.org/10.1017/S1743923X18000442.

Kommers, D. P. (1985). Liberty and community in constitutional law: The abortion cases in comparative perspective. Brigham Young University Law Review, 371-409.

Kommers, D. P. (1994). The constitutional law of abortion in Germany: Should

Kostadinov, B. (2017). Konstitucionalizacija periodnog modela prekida trudnoće u Republici Hrvatskoj [The constitutionalisation of the periodic model of abortion in the Republic of Croatia]. Informator, 6461. Retrieved from

McGuinness, S., \& Rooney, J. (2020, April 1).A legal landmark in reproductive rights: The Abortion (Northern Ireland) Regulations 2020.[Web log post]. Retrieved from

Nijsten, M. (1990). Abortion and constitutional law, A comparative European-American study, Florence: European University Institute.

Općizakon o prekidutrudnoće [General Law on the Interruption of Pregnancy], Official Gazette of the Socialist Federal Republic of Yugoslavia, Vol. XXV, Beograd 1969.

Perinčić, R. (1990). Pobačaj - činjenice I posljedice [The Abortion - Facts and Consequences]. Obnovljeniživot: časopis za filozofiju I religijske znanosti, 45(4), 262-274.

Rausch, B. (2012). Reframing Roe: Property over privacy. Berkeley J. Gender L. \& Just., 27, 28- 63.

Reingold, R. B., \&Gostin, L. O. (2019). State abortion restrictions and the new Supreme Court women's access to reproductive health services. JAMA. 322(1), 21-22. doi: 10.1001/jama.2019.8437.

Retrieved from https://www.law.cornell.edu/supremecourt/text/505/833.

Retrieved from https://www.refworld.org/docid/3ae6b38f0.html.

Retrieved from https://www.refworld.org/docid/3ae6b3aa0.htm.

Retrieved from https://www.refworld.org/docid/4538834f0.html.

Retrieved from https://www.refworld.org/docid/5268d2064.html.

Siegel, R. B. (2014). The constitutionalisation of abortion. In R. J. Cook, N.

J., Erdman,\& B. M. Dickens (Eds.), Abortion law in transnational 
perspective: Cases and controversies, Philadelphia: Philadelphia University Press.

Siegel, R. B., (2012). Dignity and sexuality: Claims on dignity in transnational debates over abortion and same-sex marriage. $\mathrm{I} \cdot \mathrm{CON}, 10$ (2), 355-379. doi:10.1093/icon/mos013.

Singh, S., Remez, L., Sedgh, G., Kwok, L., \&Onda, T. (2018). Abortion worldwide 2017. Uneven progress and unequal access, Guttmacher Institute. $\quad$ Retrieved from https://www.guttmacher.org/sites/default/files/report_pdf/abortionworldwide-2017.pdf.

Sunstein, C. R. (1992). Neutrality in constitutional law (with special reference to pornography, abortion, and surrogacy). Columbia Law Review 92, 152.

The New York Times (1972, March 10). East German parliament approves free abortion. Retrieved from https://www.nytimes.com/1972/03/10/archives/east-german-parliamentapproves-free-abortion.html.

U.S Supreme Court (1992, June 29), Planned Parenthood of Southeastern Pennsylvania v. Casey, 505 U.S. 8331992.

U.S. Supreme Court. (1973, January 22). Roe v. Wade, 410 U.S. 113 (1973). Retrived from https://www.law.cornell.edu/supremecourt/text/410/113.

UN Committee on the Elimination of Discrimination Against Women (CEDAW). (1994). CEDAW General Recommendation No. 21: Equality in Marriage and Family Relations. Retrieved from https://www.refworld.org/docid/48abd52c0.html.

UN Committee on the Elimination of Discrimination Against Women (CEDAW). (1999). General Recommendation No. 24: Article 12 of the Convention (Women and Health). A/54/38/Rev.1, chap. I. Retrieved from https://www.refworld.org/docid/453882a73.html.

UN Committee on the Elimination of Discrimination against Women (CEDAW). (2011). L.C. v. Peru, Communication No 22/2009, 50th sess, UN Doc CEDAW/C/50/D/22/2009.

UN Committee on the Elimination of Discrimination against Women (CEDAW). (2013, November 1). General Recommendation No. 30 on women in conflict prevention, conflict and post-conflict situations. $\mathrm{CEDAW} / \mathrm{C} / \mathrm{GC} / 30$.

UN Committee on the Elimination of Discrimination against Women (CEDAW). (2018, February 23). Report of the inquiry concerning the 
United Kingdom of Great Britain and Northern Ireland under article 8 of the Optional Protocol to the Convention on the Elimination of All Forms of Discrimination against Women. Retrieved from

UN Committee on the Rights of the Child (CRC). (2003, July 1). General comment No. 4 (2003): Adolescent Health and Development in the Context of the Convention on the Rights of the Child. CRC/GC/2003/4.

UN Committee on the Rights of the Child (CRC). (2013, April 17). General comment No. 15 (2013) on the right of the child to the enjoyment of the highest attainable standard of health (art. 24). CRC/C/GC/15. Retrieved from https://www.refworld.org/docid/51ef9e134.html.

UN Committee on the Rights of the Child (CRC). (2016, December 6). General comment No. 20 (2016) on the implementation of the rights of the child during adolescence. $\mathrm{CRC} / \mathrm{C} / \mathrm{GC} / 20$. Retrieved from https://www.refworld.org/docid/589dad3d4.html.

UN General Assembly. (1966, December 16). International Covenant on Civil and Political Rights. United Nations, Treaty Series, 999, 171.

UN General Assembly. (1979, December 18). Convention on the Elimination of All Forms of Discrimination Against Women. United Nations. Treaty Series, 1249, $13 . \quad$ Retrieved from https://www.refworld.org/docid/3ae6b3970.html.

UN General Assembly. (1989, November 20). Convention on the Rights of the Child. United Nations. Treaty Series, 1577, 3.

UN Human Rights Committee (HRC). (2003). K.L. v. Peru, CCPR/C/85/D/1153/2003, Communication No. 1153/2003.

UN Human Rights Committee (HRC). (2000, March 29). CCPR General Comment No. 28: Article 3 (The Equality of Rights Between Men and Women). CCPR/C/21/Rev.1/Add.10. Retrieved from https://www.refworld.org/docid/45139c9b4.html.

UN Human Rights Committee (HRC). (2016, November 17). Mellet v. Ireland, Comm. No. 2324/2013, UN Doc. CCPR/C/116/D/2324/2013. Retrieved from https://tbinternet.ohchr.org/_layouts/15/treatybodyexternal/Download.asp $\mathrm{x}$ ? symbolno=CCPR\%2FC\%2F116\%2FD\%2F2324\%2F2013.

Unofficial abridged translation into English:

Ustavni sud Republike Hrvatske [Constitutional Court of the Republic of Croatia]. (2017, February 21). Rješenje Ustavnog suda Republike Hrvatske, broj: U-I-60/1991 $i$ dr. od 21. veljače 2017. Iizdvojeno mišljenje [Ruling of the Constitutional Court of the Republic of Croatia 
no. U-I-60/1991 et al. of 21 February 2017 and the dissenting opinion]. Official Gazette of the Republic of Croatia, No. 25/17. Retrieved from

Ustavni sud Republike Hrvatske [Constitutional Court of the Republic of Croatia]. (2012, February 15). Izvješće o pravnoj snazi, prirodi I učincima ustavnih zakona zaprovedu Ustava Republike Hrvatske, broj: $U-X-$ $838 / 2012$ od 15. veljače 2012 [The report on legal force, nature and effects of constitutional acts on implementation of the Constitution of the Republic of Croatia, no. U-X-838/2012 of 15 February 2012]. Official Gazette of the Republic of Croatia, No. 20/12.

Ustavni zakon o Ustavnom sudu Republike Hrvatske [The Constitutional Act on the Constitutional Court of the Republic of Croatia]. Official Gazette of the Republic of Croatia, No. 99/99, 29/02, 49/02.

Ustavni zakon za provedbu Ustava Republike Hrvatske [The Constitutional Act on Implementation of the Constitution of the Republic of Croatia]. Official Gazetteof the Republic of Croatia, No. 110/96.

Ustav Republike Hrvatske [The Constitution of the Republic of Croatia]. Official Gazette of the Republic of Croatia, No. 56/90, 135/97, 8/98, 113/00, 124/00, 41/01, 55/01, 76/10 and 5/14.

Ustav Socijalističke Federativne Republike Jugoslavije [The Constitution of the Socialist Federal Republic of Yugoslavia]. Official Gazette of the Socialist Federal Republic of Yugoslavia, No. 8/74.

Walen, A (1997). Consensual sex without assuming the risk of carrying an unwanted fetus; another foundation for the right to an abortion. Brooklyn Law Review, 63(4),1051-1140.

Wellman, C. (2002). The concept of fetal rights. Law and Philosophy, 21, 6593.

Werner, U. (1996). The convergence of abortion regulation in Germany and the United States: A critique to Glendon's rights talk thesis. Loy. L.A. Int'l\& Comp. L. Rev., 18, 571-602.

Zakon o zdravstvenim mjerama zaostvarivanje prava na slobodno odlučivanje o rađanju djece [Act on Health Measures for Exercising the Right to Free Decision on the Birth of Children]. Official Gazette, No. 18/78, 31/86, $47 / 89$ and $88 / 09$.

Zorzi, K. (2015). The impact of the United Nations on national abortion laws. Catholic University Law Review, 65 (2), 409-428. 
